Ethos: Jurnal Penelitian dan Pengabdian Masyarakat, Vol 9 No.1, Januari 2021: 53-62

\title{
Pemahaman dan Persepsi Penyuluh Perikanan terhadap Penggunaan TEKNOLOgI INFORMASI DAN KOMUNIKASI DALAM PENYUlUhan DI KOTA BANDAR LAMPUNG
}

\author{
${ }^{1}$ Ayu Nirmala Lutfie Syarief, ${ }^{2}$ Helvi Yanfika, ${ }^{3}$ Abdul Mutolib \\ ${ }^{1,2,3}$ Magister Ilmu Penyuluhan, Pembangunan, dan Pemberdayaan Masyarakat, Program Pascasarjana, \\ Universitas Lampung, Lampung, Indonesia. \\ email: ${ }^{1}$ ayunirmalalutfies@gmail.com; ${ }^{2}$ helviyanfika@yahoo.com, ${ }^{3}$ amutolib24@yahoo.com
}

\begin{abstract}
This study aims to determine the energy of fisheries extension, internet understanding by extension fisheries and perceptions fisheries extension of the use of technology information and communication in extension. this research was conducted in the city of Bandar Lampung. This study used a purposive sampling technique. Fisheries extension amount of 12 people in the city of Bandar Lampung. The type of data used in this study are primary and secondary data. The method used in this research is a descriptive qualitative. The results of the study found that the employment of fisheries extension still did not ideally in every sub-district in Bandar Lampung City. Understanding of internet fisheries extension in the city of Bandar Lampung is still quite low. Likewise, the perception fisheries extension of the use technology information and communication seen from the purpose of using ICT in good category. The perception fisheries extension on the use technology information and communication seen from the benefits of ICTs in good category.. Another case, perception fisheries extension of the use technology information and communication seen from the implementation of extension using ICTs in the poor category.
\end{abstract}

Keywords: fisheries extension, technology information and communication

\begin{abstract}
Abstrak. Penelitian ini bertujuan untuk mengetahui ketenagaan penyuluh perikanan, pemahaman internet oleh penyuluh dan persepsi penyuluh perikanan terhadap penggunaan teknologi informasi dan komunikasi dalam penyuluhan. Penelitian ini dilakukan di Kota Bandar Lampung. Pengambilan sampel dalam penelitian ini menggunakan teknik purposive sampling. Penyuluh perikanan yang ada di Kota Bandar Lampung berjumlah 12 orang. Jenis data yang digunakan dalam penelitian ini adalah data primer dan sekunder. Metode yang digunakan dalam penelitian ini adalah metode analisis deskriptif kualitatif. Hasil penelitian diperoleh bahwa ketenagaan penyuluh masih belum memenuhi idealnya di setiap kecamatan yang ada di Kota Bandar Lampung. Pemahaman internet penyuluh perikanan di Kota Bandar Lampung masih cukup rendah. Begitu pula persepsi penyuluh terhadap penggunaan teknologi informasi dan komunikasi dilihat dari tujuan penggunann TIK dalam kategori baik. Persepsi penyuluh terhadap penggunaan teknologi informasi dan komunikasi dilihat dari manfaat TIK dalam kegiatan penyuluhan dikategorikan baik. Lain halnya dengan persepsi penyuluh terhadap penggunaan teknologi informasi dan komunikasi dilihat dari pelaksanaan penyuluhan menggunakan TIK dalam kategori kurang baik.
\end{abstract}

Kata Kunci: penyuluh, penggunaan teknologi, informasi, dan komunikasi

\section{Pendahuluan}

Penggunaan teknologi,

informasi, dan komunikasi sangat berkembang dengan pesatnya pada saat ini. Pesatnya perkembangan teknologi, komunikasi, dan informasi ini dapat dilihat dengan adanya media komunikasi yang digunakan dalam kegiatan pertukaran informasi. Salah 
satu media komunikasi yang dapat digunakan adalah penggunaan telepon genggam atau komunikasi dunia maya yang dikenal dengan internet. Kemajuan TIK (Teknologi Komunikasi dan Informasi) berpotensi menjadi peluang yang besar bagi pelaku pembangunan perikanan untuk mengembangkan program- program yang ada. Pemanfaatan teknologi komunikasi dalam pembangunan perikanan memerlukan kompetensi dari pengguna teknologi informasi dan komunikasi tersebut. Menurut penelitian Elian, Lubis, Rangkuti (2014) petani ataupun nelayan merupakan salah satu pihak yang lemah akses terhadap sumber informasi sehingga hanya dapat mengandalkan kapasitas penyuluh untuk mendampinginya mengembangkan proses belajar inovasi pertanian dan perikanan.

Fokus dari adanya penggunaan teknologi informasi dan komunikasi adalah untuk memenuhi kebutuhan sasaran seperti petani ataupun nelayan. Informasi- informasi penting tersebut adalah penting untuk pertumbuhan dan perkembangan kegiatan perikanan yang ada antara lain sasaran seperti petani ataupun nelayan dapat memeriksa informasi pasar, harga jual dan harga beli, teknologi apa yang digunakan, atau berita terkini mengenai kegiatan pertanian yang ada. Penggunaan teknologi informasi dan komunikasi ini telah membangun sistem sosial ekonomi menjadi lebih sederhana, praktis, luas, dan cepat. Mulyandari (2011), menyatakan begitu banyak hasil penelitian di bidang pertanian atau perikanan yang telah dan sedang dilaksanakan, serta akan terus ada penelitian-penelitian di masa depan. Hasil penelitian perikanan yang berupa informasi baik dalam hal teknik produksi dan pemasaran pada hakekatnya adalah untuk memperbaiki atau memecahkan masalah yang ada dalam bidang perikanan. Informasi tersebut bukan hanya sekedar konsumsi bagi para peneliti lain untuk dijadikan bahan acuan tetapi untuk para nelayan yang bertujuan terutama untuk meningkatkan taraf hidup dan kesejahteraannya, yang pada akhirnya juga untuk memenuhi kebutuhan hidup seluruh umat manusia.

Hasil penelitian perikanan dapat dipublikasikan secara umum kepada masyarakat dengan berbagai media yang ada, namun demikian, informasi hasil penelitian perikanan tersebut pada kenyataannya belum mencapai sasaran utamanya, yaitu para petani maupun nelayan yang ada. Nelayan dan petani juga dituntut untuk bisa menyesuaikan diri dengan perubahan yang terjadi agar tidak tertinggal dengan kompetitornya di daerah lain. Nelayan dan petani yang mampu menerima ide- ide atau inovasi baru akan bertahan dan berkembang sesuai kemajuan teknologi yang ada. Nelayan atau petani yang tidak mau menerima inovasi atau adopsi baru akan teknologi tentunya akan tertinggal. Pembangunan pertanian maupun perikanan antara lain dapat berhasil karena ditentukan oleh kemampuan sumberdaya manusia dalam mengelola sistem nya yang sesuai dengan perkembangan ilmu pengetahuan dan teknologi yang ada. Upaya-upaya pembangunan pertanian tidak terlepas dari peran strategis penyuluh pertanian sebagai pihak yang menjembatani sistem sosial informasi dengan sistem sosial masyarakat petani, hal tersebut semakin menegaskan pentingnya peran penyuluh pertanian. Undang-undang No.16 Tahun 2006 tentang Sistem Penyuluhan Pertanian Perikanan dan Kehutanan (SP3K) pasal 4b menyatakan bahwa fungsi sosial penyuluhan adalah mengupayakan kemudahan akses pelaku utama dan pelaku usaha ke sumber informasi, teknologi dan sumberdaya lainnya agar mereka dapat 
mengembangkan usahanya. Pada pasal 15 ayat $1 \mathrm{c}$ juga mengamanatkan bahwa Balai Penyuluhan berkewajiban menyediakan dan menyebarkan informasi tentang teknologi, sarana produksi, pembiayaan dan pasar. Penyuluh harus mengikuti pemanfaatan TIK pada era saat ini agar informasi yang akan disampaikan penyuluh kepada sasaran dapat optimal. Penelitian ini bermaksud untuk mengkaji bagaimana penggunaan internet dan pemanfaatan informasi perikanan oleh penyuluh pertanian. Secara spesifik penelitian ini bertujuan untuk menghasilkan : (1) Deskripsi mengenai ketenagaan penyuluh perikanan (2) Deskripsi pemahaman internet oleh penyuluh, (3) Deskripsi persepsi penyuluh terhadap penggunaan TIK dalam penyuluhan.

\section{Metode}

Penelitian dilakukan di Kota Bandar Lampung pada bulan JanuariFebruari 2020. Pemilihan lokasi penelitian dilakukan secara sengaja (purposive) (Singarimbun dan Effendi, 1995). Pengambilan sampel dalam penelitian ini menggunakan metode teknik purposive sampling yaitu penyuluh perikanan Kota Bandar Lampung yang berjumlah -12 orang. Pelaksanaan penelitian yang dilakukan dengan menggunakan teknik survey karena jumlah informan yang diwawancara terdiri atas 12 penyuluh perikanan yang berada di Kota Bandar Lampung pada Januari- Februari 2020. Metode penelitian ini adalah metode analisis deskriptif (Nazir, 2014). Analisis deskriptif kualitatif digunakan untuk mengetahui persepsi penyuluh terhadap penggunaan teknologi, informasi, dan komunikasi terhadap kegiatan penyuluhan. Teknik pengumpulan data menggunakan wawancara untuk mendapatkan datadata primer. Data primer adalah data yang didapat secara langsung oleh pengumpul data dan diperoleh melalui wawancara langsung dengan responden. Data primer dalam penulisan paper ini berupa bahan-bahan tertulis yang berasal dari penelitian terdahulu, jurnal, dan berbagai informasi digital yang ada di internet, dan wawancara dengan penyuluh perikanan di Kota Bandar Lampung. membuat artikel.

\section{Hasil dan Pembahasan}

\section{Penyuluhan Perikanan}

Kegiatan penyuluhan di sektor perikanan selama ini masih sangat jarang mendapat perhatian oleh negara. Berbanding terbalik dengan penyuluhan di sektor pertanian. Jika berbicara tentang penyuluhan, maka sebagian besar orang akan mempersepsikannya dengan pertanian. Padahal penyuluhan juga bergerak untuk semua sektor, termasuk di dalamnya perikanan. Penyuluhan masih sangat diperlukan untuk para nelayan dan masyarakat pesisir karena berbagai masalah yang dihadapi oleh nelayan. Keadaan mereka tidak jauh berbeda dengan keadaan petani dan penyuluh di sektor pertanian (Prayoga, 2017). Padmanagara dalam Eksanika, Riyanto (2017) telah menyatakan bahwa penyuluhan pertanian sebagai sistem pendidikan luar sekolah (non formal) untuk para petani dan keluarganya (ibu tani, pemuda tani) dengan tujuan agar mereka mampu, sanggup dan berswadaya memperbaiki/meningkatkan kesejahteraannya sendiri serta masyarakatnya. Begitu pula dengan penyuluhan perikanan juga diartikan sebagai sistem pendidikan non formal yang diperlukan oleh nelayan untuk memenuhi kebutuhan hasil- hasil laut yang ada. Pada kegiatan penyuluh perikanan di Kota Bandar Lampung penyuluh melakukan kunjungan ke kelompok satu kali dalam sebulan. 
Setiap penyuluh memegang 10 kelompok yang ada di Kota Bandar Lampung. Tetapi menurut indikator kinerja utama yang harus dicapai setiap tahunnya yaitu tenaga penyuluh perbulan bisa 3- $4 \mathrm{kali} /$ bulan dalam mengunjungi 1 kelompok yang ada.

\section{Ketenagaan Penyuluhan}

Pada saat ini kebutuhan penyuluhan secara umum di Indonesia sangat diperlukan. Ketenagaan penyuluh belum memenuhi kebutuhan idealnya. Kota Bandar Lampung memiliki lebih dari 20 kecamatan. Walaupun masyarakat yang bekerja di bidang perikanannya paling banyak pada wilayah kecamatan Bumi Waras dan Panjang tetapi kebutuhan penyuluh perikanan masih kurang. Idealnya tiga penyuluh melakukan kegiatan penyuluhan pada 1 kecamatan dengan kompetensi budidaya pengolahan dan tangkap tergantung potensi kecamatannya masing- masing, tetapi jumlah penyuluh di Kota Bandar Lampung terlampau sedikit yaitu berjumlah 12 orang. Adapun jumlah penyuluh perikanan di Kota Bandar Lampung dapat dilihat pada Tabel 1.

Tabel 1. Jumlah penyuluh perikanan di Kota Bandar Lampung

\begin{tabular}{llrr}
\hline No & Penyuluh & $\begin{array}{r}\text { Jumlah } \\
\text { (orang) }\end{array}$ & $\begin{array}{r}\text { Persentase } \\
(\%)\end{array}$ \\
\hline 1 & PNS & 8,00 & 66,67 \\
2. & Honorer & 4,00 & 33,33 \\
\hline & Jumlah & 12,00 & 100,00 \\
\hline
\end{tabular}

\footnotetext{
Penyuluh

perikanan

membutuhkan pelatihan untuk meningkatkan kemampuan penyuluh yang ada. Pendidikan dan pelatihan yang diikuti oleh penyuluh sebagian besar belum sesuai dengan kebutuhan yang ada di lapangan. Pelatihan dibutuhkan untuk membantu sasaran
}

mengerti, memahami, dan mengadopsi ide- ide atau inovasi yang dalam kegiatan perikanan yang ada. Penyuluh kota biasanya tidak dapat mengikuti semua kegiatan penyuluhan yang ada. Biasanya frekuensi dalam dua tahun hanya dua orang dari kota yang ikut dalam pelatihan yang ada. Jadi tidak semua penyuluh perikanan Kota Bandar Lampung mendapatkan pelatihan secara intensif.

Menurut penelitian Prayoga (2018) penyuluh dengan bantuan teknologi informasi mempunyai kuasa untuk menentukan nasib dirinya. Petani bisa memilih informasi apa yang dibutuhkan dan memberikan masukan serta kritikan terhadap sistem dan teknis penyuluhan yang sedang berlangsung. Dari sini bisa dilihat bahwasanya teknologi informasi telah mendukung terciptanya sistem bottom up dalam pelaksaan kegiatan penyuluhan pertanian di Indonesia. Sejalan dengan penelitian Putri dan Safitri (2018) peran penyuluh dalam proses adopsi inovasi teknologi sebagai penghubung peneliti dan petani adalah dengan mengadakan sosialisasi mengenai inovasi yang ditemukan peneliti kepada petani, menjelaskan teknik aplikasinya, dan berapa dana yang dibutuhkan untuk mengadopsi inovasi tersebut. Sebagai organisator dan dinamisator penyuluh mendorong ketua kelompok menjalankan fungsi organisasi dalam kelompok tani dan memotivasi petani untuk menerapkan inovasi yang diperkenalkan. Penyuluh sebagai teknisi memberikan contoh dilapang penerepan teknologi yang ada. Maka dari itu perlu pelatihan- pelatihan yang ada pada penyuluh pertanian.

\section{Pemahaman Internet}

Pemahaman responden mengenai internet dapat dilihat dari tingkat pengetahuan responden mengenai pengertian internet, fungsi 
internet, media untuk mengakses internet, cara atau teknis menggunakan internet, dan penggunaan internet. Keseluruhan penyuluh perikanan di Bandar Lampung sudah cukup paham tentang bagaimana memanfaatkan internet. Pemahaman responden mengenai pengertian internet merupakan pengetahuan responden mengenai maksud dari adanya internet. Fungsi dari internet merupakan pengetahuan responden mengenai fasilitas yang ada di internet. Untuk mengakses internet butuh media pendukung seperti laptop dan handphone yang memiliki fitur untuk mengakses internet serta vidio.

Menurut penelitian Sausa, Nikolay, dan Home (2016) penggunaan telepon dan video di ponsel adalah pendekatan baru untuk berhubungan dari petani-ke-petani. Pertukaran yang dapat berkontribusi untuk mengubah dan memperkuat upaya perluasan dan dengan demikian memungkinkan intensifikasi penggunaan lahan yang diperlukan, sementara juga memungkinkan sistem pertanian demokratis. Begitu pula dengan penelitian Altalb, Filipek, dan Skowron (2015) dijelaskan bahwa hasil penelitian menunjukkan bahwa pekerja penyuluh pertanian memainkan peran utama dalam transfer teknologi pertanian ke sasaran yang ada. Menurut penelitian Milovanovic (2014) fakta-fakta ini menunjukkan bahwa ada kebutuhan besar untuk teknologi dan informasi (TI), yang dapat digunakan untuk mengatasi tantangan dan perubahan dan untuk meningkatkan produksi dan pemasaran pertanian. Namun, potensi TI belum sepenuhnya dimanfaatkan pertanian. Implementasi TI di sektor pertanian dan daerah pedesaan relatif lambat dibandingkan dengan sektorsektor ekonomi lainnya di mana IT kontemporer telah dilaksanakan dengan kecepatan tinggi.
Pemahaman internet oleh penyuluh perikanan di Kota Bandar Lampung tergolong rendah karena sebagian penyuluh perikanan di Kota Bandar Lampung belum menggunakan teknologi yang ada hanya menggunakan whatsapp dalam berkomunikasi dengan sasaran yang ada. Sebagian penyuluh sudah menggunakan web blog untuk memberikan informasi seputar perkembangan teknologi penyuluhan perikanan itu sendiri. Tujuan dalam pemanfaatan internet juga antara lain untuk meningkatkan pengetahuan, pengambilkan kebutusan adanya motivasi dan keterampilan yang ada. Pada penelitian Elian, Lubis, dan Rangkuti (2014) terjadi ketimpangan pada pemanfaatan informasi pertanian oleh responden karena informasi yang diperoleh belum pada tahap disebarkan ke petani. Lebih dari separuh responden hanya membagikannya ke sesama penyuluh, bahkan masih ada responden yang memanfaatkan informasi tersebut untuk disimpan pribadi. Pada penyuluh di Kota Bandar Lampung sudah menyebarkan informasi kepada individu atau kelompok nelayan agar dapat meningkatkan kegiatan program yang berjalan. Pada penelitian Bunch, Robinson, Edwards (2015) penelitian ini menjelaskan mengenai penerapan internet. Pada penelitian ini ditemukan bahwa mayoritas guru pertanian berada dalam tahap implementasi dan konfirmasi dari proses pengambilan keputusan inovasi. Implikasi dan rekomendasi menunjukkan untuk menciptakan pengalaman pengembangan profesional bagi guru dalam tahap pengetahuan dan persuasi dari proses keputusan-inovasi untuk belajar tentang penggunaan teknologi yang efektif. Pada penelitian ini dijelaskan di sekolah pertanian para gurunya sudah menerapkan teknologi informasi yang ada seperti penggunaan diskusi papan tulis interaktif di internet 
sebagai wadah dalam menanggapi isuisu pertanian yang ada..

\section{Persepsi Penyuluh Perikanan Terhadap Penggunaan Teknologi, Informasi dan Komunikasi dalam Penyuluhan}

Berdasarkan hasil pengamatan, persepsi penyuluh terhadap penggunaan TIK dalam penyuluhan dapat dilihat dari beberapa indikator penilaian objek yang diamati, yaitu dalam segi tujuan penggunaan TIK, pelaksanaan kegiatan penyuluhan dengan TIK, dan manfaat TIK.

\section{Persepsi Penyuluh Perikanan Terhadap Tujuan Penggunaan TIK dalam Penyuluhan}

Persepsi penyuluh perikanan terhadap tujuan penggunaan TIK dalam kegiatan penyuluhan dalam kategori baik. Hal ini dikarenakan penyuluh beranggapan bahwa tujuan penggunaan TIK dalam penyuluhan yang dianjurkan oleh pemerintah pada masa sekarang ini sangat diperlukan untuk mempermudah kegiatan penyuluhan dalam mengakses informasi. Berdasarkan wawancara yang telah diajukan terkait tentang indikator penilaian dari segi tujuan penggunaan TIK dalam penyuluhan sebagian besar penyuluh telah mengetahui tujuan dari penggunaan TIK dalam penyuluhan. Penyuluh perikanan menyatakan bahwa tujuan dari penggunaan TIK dalam penyuluhan tersebut sangat baik, yaitu mempermudah nelayan untuk menerima informasi secara cepat dengan menggunakan whatsapp dan internet yang ada terkait dengan informasi terbaru perikananan yang sedang berkembang saat ini. Begitu pula dengan penelitian Muher, Erika, dan Abdul (2019) persepsi petani terhadap program billing system dilihat dari tujuan program dalam kategori baik. Hal ini dikarenakan petani beranggapan bahwa semua program yang diberikan oleh pemerintah adalah program yang diorientasikan dan bertujuan untuk kepentingan masyarakat (petani).

\section{Persepsi Penyuluh Perikanan Terhadap Pelaksanaan Kegiatan penyuluhan menggunakan TIK}

Persepsi penyuluh perikanan terhadap pelaksanaan kegiatan penyuluhan menggunakan TIK dalam kategori kurang baik. Artinya penyuluh perikanan menilai bahwa pelaksanaan kegiatan penyuluhan dengan menggunakan media telepon genggam dan media internet masih sulit dilaksanakan oleh penyuluh perikanan karena banyak faktor kelemahan dalam melaksanakan kegiatan penyuluhan tersebut. Adapun beberapa kelemahan dalam pelaksanaan kegiatan penyuluhan menggunakan internet dapat dilihat pada Tabel 2.

Tabel 2. Persepsi Penyuluh Perikanan Terhadap Pelaksanaan Kegiatan Penyuluhan dalam Menggunakan TIK

\begin{tabular}{lll}
\hline No. & Komponen & Keterangan \\
\hline 1. & Fasilitas Teknologi, Informasi, dan & 1. Tidak ada fasilitas komputer yang \\
& Komunikasi & tersedia di kelompok nelayan \\
& & $\begin{array}{l}\text { 2. Fasilitas internet sulit terhubung ke } \\
\text { sistem online }\end{array}$ \\
& $\begin{array}{l}\text { 1. Kurangnya pelatihan dalam } \\
\text { penggunaan internet bagi nelayan }\end{array}$ \\
& yang ada \\
& 2. Nelayan jarang mengakses blog yang \\
& disediakan penyuluh untuk membantu
\end{tabular}


penyebaran informasi

3.

Sumber Daya Penyuluh

1. Penyuluh perikanan membutuhkan lebih banyak pelatihan dalam meningkatkan kemampuan penyuluh terkait penggunaan TIK

2. Kurangnya jumlah penyuluh dalam memberikan kegiatan penyuluhan tentang TIK di setiap kecamatan

Pada tabel ini dijelaskan bahwa kelemahan dalam pelaksanaan kegiatan penyuluhan dalam menggunakan fasilitas TIK yaitu komponen pertama fasilitas teknologi, informasi, dan komunikasi. Pertama yaitu tidak adanya fasilitas komputer yang tersedia di kelompok nelayan yang ada. Hal ini diperlukan untuk menginput data dalam penyusunan program- program yang dibantu oleh penyuluh untuk memperoleh bantuan pemerintah. Hasil wawancara juga menjelaskan bahwa beberapa nelayan mempunyai keterampilan dan pengetahuan dalam penggunaan teknologi informasi dan komunikasi yang tergolong masih rendah. Hal ini dikarenakan untuk menggunakan komputer nelayan beranggapan bahwa untuk memahami komputer/ laptop tersebut membutuhkan waktu yang cukup lama dan membuat pekerjaan semakin sulit dan nelayan tidak ada waktu dalam mengakses komputer tersebut. Kedua, fasilitas internet sulit untuk terhubung ke sistem online. Hal ini menyulitkan petani dalam mengakses informasi yang ada. Fasilitas komputer dan internet saling terkait dalam mendukung kegiatan penyuluhan yang ada. Hal ini sesuai dengan penelitian Muher, Erika, dan Abdul (2019). Dalam penelitian ini menjelaskan bahwa persepsi petani padi terhadap program billiing system berdasarkan pelaksanaan program terganggu dengan komponen fasilitas teknologi dan pelayanan infrastruktur yang menjelaskan tidak ada fasilitas komputer, internet, serta jarak bank yang sulit dijangkau dan akses bank yang tergolong sulit. Begitu pula dengan penelitian Hary dan Maulana (2019) dijelaskan bahwa permasalahan yang dihadapi masyarakat khususnya SLB Karya Padang dan Bina Bangsa salah satunya yaitu kurangnya sarana dan prasarana yang menunjang pembelajaran berbasis TIK (Teknologi Informasi dan Komputer) seperti komputer, projektor, dan pengeras suara (speaker). Menurut penelitian Fajar, Rohaeni, dkk (2017) kendala dalam pelatihan TIK antara lain kendala koneksi internet yang kurang mendukung. Begitu pula sarana dan prasarana yang kurang memadai.

Komponen yang kedua yang mempengaruhi pelaksanaan kegiatan penyuluhan menggunakan TIK adalah sumber daya nelayan yaitu kurangnya pelatihan dalam penggunaan internet bagi nelayan yang ada. Perlu adanya pelatihan internet untuk mendukung nelayan agar cepat menerima informasi dan mendukung dalam pengolahan data yang didapat. Selain itu penyuluh sudah menyediakan web-blog untuk membantu nelayan dalam belajar dan mengumpulkan informasi terkait dalam mengembangkan usahanya agar lebih maju. Tetapi nelayan sangat jarang mengakses blog yang disediakan penyuluh untuk membantu dalam penyebaran informasi yang ada. Para nelayan di daerah pelabuhan panjang 
tidak semua memiliki telepon untuk mengakses informasi yang ada. Pada saat melakukan penyuluhan, penyuluh memberikan informasi dengan laptop. Kebanyakan penyuluh perikanan menggunakan pendekatan secara langsung melalui individu atau kelompok nelayan yang ada. Kebanyakan nelayan belum mengakses internet yang ada. Penyuluh perikanan Kota Bandar Lampung belum menggunakan media sosial seperti facebook, twitter, atau web resmi dalam menunjang kegiatannya. Menurut penelitian Prawiranegara, Sumardjo, Lubis, dan Harijati (2016) meskipun masih terdapat beberapa kendala terkait kualitas informasi sehingga menjadikan sulitnya informasi utamanya inovasi untuk diadopsi, informasi melalui internet sebenarnya dapat menyediakan kesempatan yang lebih besar untuk mencapai suatu tingkatan tertentu yang lebih baik bagi sasaran secara keseluruhan apabila didukung oleh peran sumber informasi yang memanfaatkan media informasi sebagai media penyebaran inovasi. Penyuluh perikanan Kota Bandar Lampung belum menggunakan media sosial seperti facebook, twitter, ataui web resmi dalam menunjang kegiatannya. Berbeda dengan penelitian Prayoga (2017) bahwa ternyata secara keseluruhan media sosial seperti facebook dan twitter telah digunakan untuk menunjang kegiatan penyuluhan dan pertukaran informasi yang ada.

Komponen yang ketiga sangat berkaitan dengan komponen yang kedua yaitu sumber daya penyuluh. Hasil wawancara kepada penyuluh menjelaskan bahwa beberapa faktor ini dapat mempengaruhi buruknya kualitas penyuluhan terkait sumberdaya penyuluh antara lain tidak hanya nelayan saja yang membutuhkan pelatihan tetapi diharapkan pemerintah dapat menyediakan lebih banyak pelatihan dalam meningkatkan kemampuan penyuluh terkait penggunaan TIK. Tidak hanya pelatihan dasar saja, tetapi penggunaan aplikasi yang dapat mendukung kegiatan penyuluhan perlu dilakukan untuk mendukung agenda kegiatan penyuluhan perikanan agar dapat lebih berkembang. Faktor yang kedua dapat dilihat dari kurangnya jumlah penyuluh dalam memberikan kegiatan penyuluhan tentang penggunaan TIK di setiap kecamatan. Hal ini dapat mempengaruhi kinerja penyuluh sehingga penyuluh selalu merasa kewalahan dalam menangani kegiatan penyuluhan yang harus terus menerus berkembang.

\section{Persepsi Penyuluh Perikanan Terhadap Manfaat TIK dalam Penyuluhan}

Persepsi penyuluh perikanan terhadap manfaat TIK dalam kegiatan penyuluhan dalam kategori baik. Hal ini dikarenakan penyuluh beranggapan bahwa manfaat TIK dalam penyuluhan yang dirasakan nyata dari hasil penelitian adalah waktu menjadi lebih efisien karena berhubungan dengan sesama nelayan dan penyuluh dapat menggunakan whatsapp untuk mengatur pertemuan agar lebih fleksibel. Selain itu, karena penggunaan TIK dalam penyuluhan dapat meningkatkan kesadaran nelayan untuk dapat meningkatkan produksi dan kualitas hasil tangkapan dan dapat meningkatkan keterampilan nelayan pada era sekarang ini. Hal ini sesuai dengan penelitian Muher, Erika, dan Abdul (2019) bahwa manfaat terhadap program billing system dapat membantu petani peningkatkan pendapatan karena harga pupuk subsidi yang diterima petani lebih murah. Selain itu berdampak positif terhadap pengetahuan dan keterampilan usaha tani. 


\section{Kesimpulan dan Saran}

Pada saat ini kebutuhan penyuluhan secara umum di Indonesia sangat diperlukan. Ketenagaan penyuluhan belum memenuhi kebutuhan idealnya di Bandar Lampung. Kota Bandar Lampung memiliki lebih dari 20 kecamatan. Idealnya tiga penyuluh melakukan kegiatan penyuluhan pada 1 kecamatan dengan kompetensi budidaya pengolahan dan tangkap tergantung potensi kecamatannya masing- masing, tetapi jumlah penyuluh di Kota Bandar Lampung terlampau sedikit yaitu berjumlah 12 orang. Pemahaman internet oleh penyuluh perikanan di Kota Bandar Lampung tergolong rendah karena penyuluh perikanan di Kota Bandar Lampung belum menggunakan teknologi yang ada hanya menggunakan whatsapp dalam berkomunikasi dengan sasaran yang ada. Sebagian penyuluh sudah menggunakan web blog untuk memberikan informasi seputar perkembangan teknologi penyuluhan perikanan itu sendiri.

Persepsi penyuluh terhadap penggunaan TIK dalam penyuluhan dapat dilihat dari beberapa indikator penilaian objek yang diamati, yaitu dalam segi tujuan penggunaan TIK dalam kategori baik. Hal ini dikarenakan penyuluh beranggapan bahwa tujuan penggunaan TIK dalam penyuluhan yang dianjurkan oleh pemerintah pada masa sekarang ini sangat diperlukan untuk mempermudah kegiatan penyuluhan dalam mengakses informasi.

Persepsi penyuluh perikanan terhadap pelaksanaan kegiatan penyuluhan menggunakan TIK dalam kategori kurang baik. Artinya penyuluh perikanan menilai bahwa pelaksanaan kegiatan penyuluhan dengan menggunakan media telepon genggam dan media internet masih sulit dilaksanakan oleh penyuluh perikanan karena banyak faktor kelemahan dalam melaksanakan kegiatan penyuluhan tersebut yaitu lemahnya komponen fasilitas teknologi, informasi, dan komunikasi, sumberdaya nelayan, dan sumberdaya penyuluh yang ada. Persepsi penyuluh perikanan terhadap manfaat TIK dalam kegiatan penyuluhan dalam kategori baik. Hal ini dikarenakan penyuluh beranggapan bahwa manfaat TIK dalam penyuluhan yang dirasakan nyata dari hasil penelitian adalah waktu menjadi lebih efisien karena berhubungan dengan sesama nelayan dan penyuluh dapat menggunakan whatsapp untuk mengatur pertemuan agar lebih fleksibel. Selain itu, karena penggunaan TIK dalam penyuluhan dapat meningkatkan kesadaran nelayan untuk dapat meningkatkan produksi dan kualitas hasil tangkapan dan dapat meningkatkan keterampilan nelayan pada era sekarang ini.

\section{DAFTAR PUSTAKA}

Altalb AAT, Filipek T, dan Skowron P. 2015. The Role of Agricultural Extension in the Transfer and Adoption of Agricultural Technologies. Journal Of Agriculture and Food Sciences: Vol 3 (5): 500-507 (10 Maret 2020).

Bunch JC, Robinson JS, dan Edwards MC. 2015. Agriculture Teachers' Use of Interactive Whiteboards (IWBs): Teachers' Perceptions of Innovativeness and Technology Integration. Journal of Human Sciences and Extension, 3(1), 63-79 (10 Maret 2020).

Eksanika P, dan Riyanto S. 2017. Pemanfaatan Internet Oleh Penyuluh Pertanian. Jurnal Sains Komunikasi dan Pengembangan Masyarakat:Vol 1(1): 65-80. (9 Maret 2020). 
Elian N, Lubis DP, dan Rangkuti PA. 2014. Penggunaan Internet dan Pemanfaatan Informasi Pertanian Oleh Penyuluh Pertanian di Kabupaten Bogor Wilayah Barat. Jurnal Komunikasi Pembangunan: Vol 12 (2): 104-110 (10 Maret 2020).

Fajar MY, Rohaeni, dkk (2017). Meningkatkan Kompetensi Guru SMA dan Sederajat Melalui Pelatihan Pembelajaran Berbasis TIK. ETHOS: Jurnal Penelitian dan Pengabdian Masyarakat 5(2):175181 (9 Maret 2020).

Hary DR dan Maulana IT. 2019. Upaya Peningkatan Penerapan IPTEKS Melalui Pelatihan dan Peningkatan Kualitas Guru Serta Nilai Tambah Jasa Pelayanan SLB. ETHOS: Jurnal Penelitian dan Pengabdian Masyarakat 7(1):77-87 (9 Maret 2020).

Milovanovic S. 2014. The Role And Potential Of Information Technology In Agricultural Improvement. Journal Economics Of Agriculture: Vol 61 (2): 471-485 (10 Maret 2020).

Muher, Erika, dan Abdul. 2019. Persepsi Petani Terhadap Program Billing System di Kecamatan Metro Barat Kota Metro. Jurnal Pemikiran Masyarakat Ilmiah Berwawasan Agribisnis Vol 5(1): 114-123 (9 Maret 2020).

Mulyandari, RSH. 2011. Perilaku Petani Sayuran dalam Memanfaatkan Teknologi Informasi. Jurnal Perpustakaan Pertanian 20(1): 22-34 (10 Maret 2020)

Nazir. 2014. Metode Penelitian. Ghalia Indonesia. Bogor:

Prayoga K. 2017. Pemanfaatan Media Sosial Dalam Penyuluhan Pertanian dan Perikanan di Indonesia. Jurnal
Sosial Ekonomi dan Kebijakan Pertanian: Vol 6 (1): 33- 43

(10 Maret 2020).

Prayoga K. 2018. Dampak Penetrasi Teknologi Informasi Dalam Transformasi Sistem Penyuluhan Pertanian di Indonesia. Jurnal Penyuluhan dan Komunikasi Pembangunan: Vol 14 (1): 46- 59 (9 Maret 2020).

Putri RK dan Safitri R. 2018. Peran Penyuluh Pertanian Terhadap Penerapan Teknologi Tanap Jajar Legowo 2:1 (Kasus Kelompok Tani Gotong Royong 2 di Desa Klaseman, Kabupaten Probolinggo. Jurnal Ekonomi Pertanian dan Agribisnis (JEPA): Vol 2(3): 167178 (9 Maret 2020).

Tiamiyu SA, Usman A, dan Ugalahi UB. 2014. Adoption of On-farm and Post-harvest Rice Quality Enhancing Technologies in Nigeria. Journal Tropicultura :32(2): 67-72 ( 10 Maret 2020).

Sausa F, Nicolay G, dan Home R. 2016. Information technologies as a tool for agricultural extension and farmerto-farmer exchange: Mobilephone video use in Mali and Burkina Faso. International Journal Of Education and Development Using Information and Communication Technology (IJEDICT): Vol 12 (3): 19- 36 (9 Maret 2020).

Suvedi M, Ghimeri R, dan Kaplowitz M. 2017. Farmers' participation in extension programs and technology adoption in rural Nepal: a logistic regression analysis. Journal of Agricultural Education And Extension: 1-21. (10 Maret 2020). 